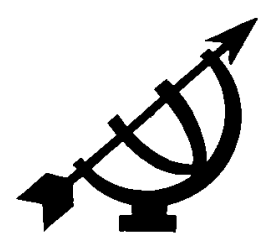

\title{
'n Beknopte regshistoriese oorsig van die vereistes vir die totstandkoming van 'n regsgeldige huwelik
}

\author{
J.A. Robinson \\ Fakulteit Regte \\ Potchefstroomkampus \\ Noordwes-Universiteit \\ POTCHEFSTROOM \\ E-pos: pvrjar@puknet.puk.ac.za
}

\begin{abstract}
A concise legal-historical overview of the requirements for establishing a legally valid marriage

Within the Reformational tradition it is commonly accepted that marriage does not only have a typical and unique character, but that it also reflects the relationship between Christ and his church. This article focuses on the legal requirements for the solemnisation of a marriage in contemporary South African law against the legalhistorical background to the issue. In view of the fact that the formalities for solemnisation are aimed at legal certainty and the prevention of clandestine marriages, the conclusion is reached that the church may prescribe requirements for the establishment of a marriage within the parameters of its own dogma and for its own internal purposes. It is argued that the church should apply this perspective regarding members of a congregation who are involved in a long-standing relationship, but for reasons of their own, prefer not to enter into a legally recognised marriage.
\end{abstract}

\section{Opsomming}

'n Beknopte regshistoriese oorsig van die vereistes vir die totstandkoming van 'n regsgeldige huwelik

Vanuit die gereformeerde (Reformatoriese) tradisie word algemeen aanvaar dat die huwelik nie alleen 'n tipiese en unieke aard het nie, maar ook dat dit die verhouding tussen Christus en sy kerk vergestalt. Hierdie artikel fokus vanuit regshistoriese perspektief op die vereistes wat tans van owerheidsweë vir die formele bevestiging van huwelike gestel word. In die lig van die feit dat formaliteite vir die regsgeldige 
sluiting van huwelike gestel word ter wille van regsekerheid en om klandestine huwelike te verhoed, word tot die gevolgtrekking gekom dat die kerk, vir sy eie interne doeleindes, voorskrifte mag stel vir die totstandkoming van 'n huwelik binne die raamwerk van sy eie dogma en leer. Kerke behoort vanuit hierdie perspektief met lidmate om te gaan wat in 'n langdurige saamwoonverhouding betrokke is, maar wat vanweë persoonlike redes verkies om nie 'n regsgeldige huwelik te sluit nie.

\section{Inleiding}

Vanuit die gereformeerde (Reformatoriese) tradisie word aanvaar dat die huwelik as instelling, soos alles wat God geskape het, 'n eiesoortige aard het én op God se verheerliking gerig behoort te wees. Vanuit hierdie vertrekpunt word, teen die agtergrond van Efesiërs 5:31, geleer dat die sin en doel van die huwelik daarin geleë is dat dit moet dien tot die verryking en verdieping van huweliksgades se onderlinge verhouding. Hierdie verryking en verinniging kom in sowel hulle onderlinge liefdesbetoon as in die seksuele verkeer tussen hulle tot uiting (Heyns, 1981:53; Douma, 1994:17). In Efesiërs 5:32 word gestel dat die huweliksverhouding 'n afskaduwing moet wees van die verhouding van Christus met sy kerk. Binne die juridiese sfeer word die eiesoortige aard van die huwelik verdiskonteer deur te aanvaar dat die huwelik as instelling in die biologiese verskille tussen ' $n$ man en ' $n$ vrou gefundeer is. Hierdie geslagtelike basis kom tot vervulling in die seksuele omgang tussen die partye en bied daardeur die waarborg vir die eenheid van die huwelik. Die geslagtelike basis word deur die etiese, die liefde, gerig (Joshua $v$ Joshua 19611 SA 455 (GW); Grobbelaar v Havenga 19643 SA 522 (W); T v T 19683 SA 554 (R)).

Die huwelik as instelling kom in Suid-Afrika in die nuwe konstitusionele bedeling toenemend onder druk. So word byvoorbeeld gevind dat gevolge wat van regsweë eiesoortig aan die huweliksbedeling geknoop is, nou op ad hoc-grondslag na homoseksuele verbintenisse uitgebrei word. ${ }^{1}$ Eweneens kom die formali-

1 Vgl. onder andere Langemaat $v$ Minister of Safety and Security 19982 All SA 259 (T); Satchwell v President of the Republic of South Africa 20026 SA 1 (CC); Du Toit v Minister of Welfare and Population Development 2001 (12) BCLR 1225 (T). In Fourie \& Bonthuys v Minister of Home Affairs Saak no 232/2003 (tans ongerapporteer) maak die Hoë Hof van Appèl die volgende bevel: "It is declared that: ... In terms of sections ... of the Constitution, the common law concept of marriage is developed to embrace same-sex partners as follows: 'Marriage is the union of two persons to the exclusion of all others for life'". (kursivering - JAR). 
teite wat vir die sluiting van 'n regsgeldige huwelik gestel word ook vanuit 'n verskeidenheid oorde toenemend onder die loep. ${ }^{2}$ In hierdie artikel handel dit oor die optrede van kerke binne die gereformeerde (Reformatoriese) tradisie jeens lidmate (vir die doeleindes van hierdie beredenering, wel van die teenoorgestelde geslag) wat om 'n verskeidenheid van redes verkies om nie formeel 'n regsgeldige huwelik te sluit nie. In die lig van die belydenisskrifte van sodanige kerke word gevra hoedanig die kerk se benadering behoort te wees met verwysing na aspekte soos die gebruik van Nagmaal, die kerklike tug, ensovoorts. ${ }^{3}$

Teen die agtergrond van bostaande paragraaf slaan die kern van hierdie artikel op die vraag in welke mate kerke die regsgeldigheid van huwelike as eie verwysingspunt behoort te aanvaar. Die beredenering knoop daarom aan by die die reg wat geld vir persone as lede van onderskeidelik die staatlike gemeenskap én as lede van ander gemeenskappe as die staat. Statutêre norme en voorskrifte wat tans geld, word vanuit regshistoriese perspektief belig ten einde 'n geldige betekenis aan sodanige voorskrifte te heg.

2 So kan die Wet op Erkenning van Gebruiklike Huwelike 120 van 1998 aangemerk word as 'n uitsondering op die gemeenregtelike voorskrif dat 'n huwelik 'n regsverhouding tussen een man en een vrou is. Daarbenewens verskil die vereistes vir die totstandkoming van dié huwelik aansienlik van dié wat in die Huwelikswet 25 van 1961 gestel word.

3 Artikel 70 van die Dordtse Kerkorde (1618/1619) wat op die Sinode van Reddersburg van 1862 as kerkorde vir die Gereformeerde Kerke in Suid-Afrika aanvaar is, bepaal byvoorbeeld dat kerkrade moet toesien dat die huwelik aangegaan word as heilige verbintenis in die Here volgens die formulier wat daarvoor vasgestel is. Die Formulier vir die Huweliksbevestiging benadruk dat die huwelik ' $n$ eerbare verhouding is, omdat dit ' $n$ afbeelding van die verhouding tussen Christus en die gemeente is. Die voorgeskrewe formule lui soos volg:

\begin{abstract}
$A B$, $u$ het hier voor God en almal teenwoordig verklaar dat $u C D$ as $u$ wettige vrou neem. Beloof $u$ dat $u$ haar nooit sal verlaat nie, dat $u$ haar sal liefhê en getrou sal onderhou soos 'n getroue en Godvresende man aan sy vrou verskuldig is? Beloof $u$ verder dat $u$ heilig met haar sal lewe en haar in alles getrou sal bly ooreenkomstig die uitspraak van die heilige evangelie? (Die berymde Psalms en Skrifberymings, 1987:667).
\end{abstract}

Nadat dieselfde formule aan die ander party gestel is en albei partye bevestigend geantwoord het, kom die huwelik tot stand wanneer die bedienaar verklaar dat die partye regtens getroud is. 


\section{Regshistoriese perspektiewe op die vereistes vir die totstandkoming van huwelike}

\subsection{Romeinse reg}

In die Romeinse reg word die huwelik deur Justineanus beskryf as die vereniging van 'n man en 'n vrou wat 'n verhouding van onafskeidelike saamleef daarstel. Daar is aanvanklik twee huweliksvorme erken, naamlik met (cum) en sonder (sine) gesag (manus). Die huwelik cum manu het meegebring dat die vrou uit die familie (familia) van haar vader (pater) gegaan het en 'n verwant (agnata) van die familia van haar man geword het (Van Warmelo, 1971:68). Sy het met ander woorde onder die gesag (potestas) van haar man of dié se vader gekom. Die vestiging van die gesag kon op drie wyses geskied.

- In die eerste plek kon dit deur confarreatio geskied. Hierdie godsdienstige handeling het ingehou dat 'n vrou deur die offer van 'n broodjie van die beskerming van haar vroeëre huisgode losgemaak is en onder die beskerming van die huisgode van die man geplaas is. 4

- Tweedens kon gesag gevestig word deur coemptio. Volgens hierdie gebruik is die vrou in 'n skynverkoping onder die gesag van haar man geplaas. Die primêre bedoeling was daarom nie om 'n huweliksverhouding tussen haar en haar man tot stand te bring nie.

- In die derde plek kon die huwelik tot stand kom deur gebruik (usus) wat bestaan het uit wilsooreenstemming tussen die partye, tesame met die totstandkoming van die huweliksgemeenskap. Dit kon byvoorbeeld gebeur dat iets met die formele voorskrifte by confarreatio of coemptio verkeerd geloop het, wat tot gevolg sou hê dat die vrou nie in die manus van haar man sou val nie.

$4 \quad$ Muirhead (1899:25) verduidelik dat dit 'n religieuse verpligting was om in die huwelik te tree. Hierdie verpligting was deur die man aan sy voorvaders en homself verskuldig en het op die geloof berus dat die geluk van die dooies afgehang het van 'n behoorlike begrafnis en die voortdurende feeste en offerandes van afstammelinge, waardeur boete vir hulle siele gedoen is. Daar is geglo dat daar 'n verpligting op 'n man rus om sy eie ras se voortbestaan te verseker en om sy familietradisies voort te sit. Deur die sluiting van 'n huwelik op hierdie wyse het die man die vrou uit die huis van haar vader geneem en haar by sy familietradisies ingelyf - binne die stand van die patrisiërs kon dit alleen met goddelike goedkeuring geskied. Die seremonie het ' $n$ religieuse aard gehad en dit is deur die hoëpriester van die staat in die teenwoordigheid van tien getuies uitgevoer. Hierdie getuies was van die stam van die bruidegom. 
Oorspronklik was so 'n situasie vir die Romeine onhoudbaar en daarom kon gesag ook deur usus (gebruik of besit) tot stand kom. Die proses waarvolgens manus in hierdie omstandighede gevestig is, het gewentel om die reël dat iemand eienaar van 'n saak kon word deur dit vir 'n sekere tyd onder bepaalde omstandighede te besit. Indien 'n man sy vrou dus vir een jaar "besit", sou hy gesag oor haar verkry. Dit was egter belangrik dat hierdie besit nie onderbreek moes word nie. Sodanige onderbreking sou, volgens die Twaalf Tafels (lex xii tabularum), voorkom as die vrou vir ten minste drie agtereenvolgende nagte afwesig sou wees - die sogenaamde trinoctii absentia.

Teenoor die huwelik cum manu is die bestaan van 'n huwelik met uitsluiting van gesag (sine manu) reeds vanaf 'n vroeë stadium erken. Hierdie vorm van huweliksluiting was die gevolg van veranderinge in siening van die familieverhouding en ook van veranderde sienings rondom die status van die vrou. In toenemende mate is erkenning daaraan gegee dat die vrou meer selfstandig en onafhanklik in die gemeenskap moes optree, sodat haar status meer gelykvormig aan dié van haar man sou wees. Met hierdie huweliksvorm is gepoog om die wenslikheid daarvan te beklemtoon dat man en vrou eerder binne 'n huwelik as in 'n konkubinaatsverhouding moes saamleef. Die vereistes vir hierdie huweliksvorm was derhalwe wilsooreenstemming (consensus facit nuptias) en huweliksgemeenskap. Wat die aspek van wilsooreenstemming betref, moes die partye dus te kenne gee dat hulle nie in 'n blote concubinatus betrokke wou wees nie, maar inderdaad regtens 'n huwelik wou sluit. Die tweede vereiste het behels dat die partye die woning van die man gesamentlik moes betree (deductio in domum). Dié vereiste het later afgewater, sodat die vrou ook in die afwesigheid van die man na sy woning kon gaan. Ingevolge hierdie huweliksvorm het die vrou nie deel van die man se familia geword nie. Met verloop van tyd het die huwelik sine manu die huwelik cum manu verdring. Die huwelik wat deur Justineanus beskryf word, is trouens die huwelik sine manu - die huwelik cum manu het in die latere Romeinse reg volledig verdwyn.

Op grond van hierdie bespreking blyk dit dat 'n huwelik deur gebruik (usus) cum manu kon word as dit nie van die begin af deur confarreatio of coemptio so gesluit is nie. Met die trinoctii absentia kon dit egter verhoed word. Die trinoctii absentia het later oorbodig geword, want namate die huwelik cum manu in onbruik geraak het, het confarreatio slegs ' $n$ sakrale betekenis verkry en is coemptio aangewend om iets anders as 'n huwelik cum manu in die lewe te roep. Wat usus betref, is die trinoctii absentia deels deur wetgewing 
herroep en deels het dit deur onbruik verval. Dit het dus beteken dat 'n regsgeldige huwelik deur ooreenkoms en die begin van huweliksgemeenskap tot stand gekom het sonder dat daar van manus sprake was. Die huwelik sine manu het meegebring dat die vrou dieselfde maatskaplike rang en aansien as haar man geniet het. Die vrou moes getrou aan haar man wees en die gades moes oor en weer eerbied aan mekaar betoon. Sonder 'n egskeiding kon hy haar nie verjaag nie. 5

Dit is dus duidelik dat die oorgang van 'n verlowing tot die huwelikstaat self nie deur 'n besondere huwelikseremonie gekenmerk is nie. Die blote (selfs informele) wilsooreenstemming (aanvanklik tesame met en later sonder) die deductio in domum het 'n geldige huwelik daargestel. 6 In Digesta 50.17.30 word daarom gestel dat wilsooreenstemming 'n huwelik tot stand bring en nie saamslaap nie (nuptias non concubitus, sed consensus facit).

\subsection{Germaanse reg (vroeë Kontinentale reg)}

In hierdie periode het die huwelik in vele opsigte ooreenkomste getoon met die hedendaagse lobolo-huwelik van die inheemse bevolking van Suid-Afrika - dit was eerder 'n ooreenkoms tussen twee families as tussen twee individue (Hahlo, 1969:4; De Blécourt \& Fischer, 1950:65). Die huwelik het deur 'n uitgebreide familieooreenkoms tot stand gekom. Die bruidegom het sy bruid van haar vader gekoop of haar geroof. Tacitus verduidelik dat dit juis die ooreenkoms is wat die huwelik tussen die partye tot stand bring. ${ }^{7}$ Dit is egter onduidelik of Tacitus met die verdere uiteensetting dat dit nie die vrou is wat aan die man 'n bruidskat gee nie, maar die man

5 Vgl. Van Warmelo (1965:75). Hahlo (1969:1) verduidelik dat "[t]he informal consent marriage of later Roman law did not affect the general status of the wife. She did not change her agnatic family, and did not become subject to the power of her husband or his pater familias ... (b)ut her husband had the ius mariti, entitling him to determine all matters incidental to the common life of the spouses, such as residence, household expenditure and education of children."

$6 \quad$ Vgl. Moyle (1912:128); Van der Vyver en Joubert (1991:459). Voet se Commentarius ad Pandectas Boek 23 Titel 2, vertaal deur Stoney (1896 hierna Stoney, 1896), verklaar met verwysing na Digesta 50.17.30 dat "[A]ccording to Roman law marriage is contracted by consent, in what ever manner it is expressed, either by words or by act, and even by cohabitation alone." Kyk ook Hahlo (1969:1).

7 Aangehaal in De Blécourt en Fischer (1950:65). Die skrywers vermeld dat ofskoon uxori beteken "aan die vrou", dit verstaan moet word asof daar staan "aan die familie van die vrou". 
aan die vrou (dotem non uxor marito, sed maritus uxori offert), die betaling van ' $n$ koopprys aan die vader van die bruid bedoel. De Blécourt en Fischer (1950:65) dui egter aan dat as sommig leges barbarorum letterlik vertolk sou word, dit eerder lyk asof die man die voogdy oor die vrou (mundium) van haar vader gekoop het. $\mathrm{Na}$ verloop van 'n tydperk is in elk geval aanvaar dat die man die mundium oor die vrou gekoop het. Ná betaling het lewering (traditio puellae) gevolg, maar eers ná die lewering is die huwelik deur geslagsgemeenskap voltrek. Oorspronklik was die toestemming van die vrou nie vereis nie.

$\mathrm{Na}$ die vyfde eeu het die Christelike leer in toenemende mate die Germaanse reg beïnvloed. Poligamie was verbied en verbode grade van verwantskap is uiteengesit. Die man het steeds die bruid "gekoop", maar in wese was die huwelik nou 'n ooreenkoms tussen die bruid en die bruidegom. Haar toestemming was nou ook vir die huwelik vereis. Die vergoeding wat vir die vrou betaal is (pretium nuptiale) het ook van aard verander - dit was nie meer 'n koopprys van die man aan die familie van die vrou nie, maar eerder 'n bevoordeling of bruidskat (wittum, dos) wat deur hom tot die voordeel van die vrou onderneem is (Hahlo, 1969:5; De Blécourt \& Fischer, 1950:66). Van verdere belang vir die onderhawige bespreking is die feit dat diegene wat voorheen die vrou of die mundium oor haar verkoop het, nou slegs toestemming tot die huwelik gegee het. 8

Dit is dus duidelik dat in die vroeë Germaanse reg "koop" en "lewering" en later wilsooreenstemming tussen bruid en bruidegom (die huweliksbelofte) gevolg deur saamslaap en saamwoon 'n huwelik tot stand gebring het. Blote saamwoon sonder die huweliksbelofte was gewoon 'n konkubinaatsverhouding. Teen die einde van die Germaanse periode het dit vir 'n paar gebruiklik geword om hulle huwelik die oggend ná die eerste huweliksnag deur 'n priester te laat inseën. Dit was egter geensins 'n vereiste vir die geldigheid van die huwelik nie (Hahlo, 1969:5; De Blécourt \& Fischer, 1950:66).

8 Die sogenaamde arrha ('n ring of geldsom) is ook 'n verskynsel van hierdie periode. Dit was 'n bewys van die bestaan van 'n verlowing waaruit ook bepaalde vermoedens ontstaan het, onder andere die bestaan van 'n verlowing as dit ontken sou word. 


\subsection{Die Kanonieke reg}

Gedurende die Middeleeue het die invloed van die Kerk op die huweliksreg sterk na vore gekom en die huwelik is toe as 'n sakrament gesien.9 In voortsetting van latere gebruike wat gegeld het gedurende die periode van die Germaanse reg, het huweliksluiting geskied deurdat die egpaar hulle huweliksbeloftes in die kerk voor getuies afgelê het. Daarna het 'n priester die huwelik bevestig en die seën daaroor uitgespreek. Hahlo beklemtoon egter dat dit die toestemming van die partye was en nié die seën deur die priester nie, wat die huwelik tot stand gebring het (Hahlo, 1969:7; De Blécourt \& Fischer, 1950:67; Van der Vyver \& Joubert, 1991:459). Hierdie feit word onder andere daardeur beklemtoon dat 'n verlowingskontrak deur saamslaap (copula carnalis) in 'n huwelik verander het indien geeneen van die partye intussen 'n huwelik met 'n derde aangegaan het nie. 10

De Blécourt en Fischer (1950:66) haal ene Dom. A van Roy soos volg aan wat die sakramentele aard van die huwelik betref: "De Katechismus der Nederlandsche Bisdommen noemt het huwelijk: 'het sacrament, waardoor man en vrouw zich tot echtgenooten verbinden, en genade ontvangen, om de plichten van den huwelijken staat naar behooren te ontvangen.' Volgens deze definitie is het echtverdrag zelf dus sacrament. Van dit verdrag of contact geven de echtgenooten uitwendig blijk door elkander wederzijds hun toestemming te geven in zake de overdracht en aanneming der huwelijksrechten. De sluiters van de huwelijksovereenkomst zijn dus zoowel de bedienaren en de voltrekkers als de ontvangers van de sacrament. De priester, die hun het jawoord afneemt, is slechts de gevolmachtigde getuige der Katholieke kerk en de bedienaren der liturgische plechtigheid hiermede verbonden." Vergelyk ook Dooyeweerd (1957:304 e.v.) wat daarop wys dat die benadering van die kerk die huweliksverhouding teken as ' $n$ afskynsel van die verhouding tussen Christus en sy kerk. As sodanig is die huwelik dus 'n genadegawe van God aan die mens.

10 Aanvanklik het daar onduidelikheid bestaan oor die vraag of blote wilsooreenstemming die huwelik tot stand gebring het en of copula carnalis ook vereis was. In die negende eeu voer Biskop Hincmar van Rheims aan dat daar geen geldige huwelik sonder copula carnalis kan wees nie. In die twaalfde eeu verduidelik Petrus Lombardus, Biskop van Parys, egter dat 'n huwelik deur wilsooreenstemming tot stand kom. Die Kanonieke reg het derhalwe 'n kompromisposisie ingeneem - wilsooreenstemming het 'n matrimonium initiatum tot stand gebring wat wel bindend was, maar wat nog nie 'n sakramentele aard gehad het nie. Die sakramentele aard sou eers deur copula carnalis teweeggebring word. 'n Matrimonium initiatum kon deur 'n spesiale goedkeuring van die pous ontbind word en dit het ook outomaties ontbind as een van die partye in 'n matrimonium spirituale betrokke geraak het deur in 'n klooster opgeneem te word. 'n Uitsondering is egter op hierdie reël geskep op grond van 1 Korintiërs 7:12-15. As 'n nie-Christen tot Christen bekeer is en sy of haar gade het geweier om in vrede met hom of haar saam te leef, kon die huwelik tersyde gestel word. 
Aanvanklik was daar nie eensgesindheid oor die vraag of die huwelik eers gekonsumeer moes word alvorens dit beskou kon word as finaal voltrek nie.11 Gedurende latere ontwikkeling het die standpunt dat dit nie die geval is nie, egter veld gewen. Daardeur word verdere gesag daarvoor gebied dat wilsooreenstemming tussen die partye die huwelik tot stand bring. Van der Vyver en Joubert (1991:459) toon daarom tereg aan dat die argument dat wilsooreenstemming die grondslag van die huwelik is, dermate gevestig geraak het dat 'n huwelik wat bevestig en ingeseën was, geldig was al sou die ouers of familie van die huwelikspartye nie tot die huweliksluiting ingestem het nie.

Die feit dat wilsooreenstemming voldoende was om 'n huwelik daar te stel (consensus facit nuptias), het vanuit die Kerk ernstige besware ontlok.12 Die besware het veral daarom gewentel dat klandestine huwelike binne dié bedeling gesluit kon word.13 Daarom het die Vierde Lateraanse Konsilie van 1215 vereis dat die gebooie drie maal in die kerk afgekondig moes word. Ter bekamping van sodanige huwelike is voorts ook vereis dat 'n priester die huwelik moes inseën. Nieteenstaande hierdie voorskrifte, was huwelike wat in stryd daarmee gesluit is, nie nietig nie en kon (hoogstens) tugmaatreëls van kerklike weë volg.

De door de Kerk aan het Romeinse recht ontleende regel: consensus facit nuptias bracht grote bezwaren mede. Wel schreef

11 Dit was egter na aanleiding van Matteus 19:6 duidelik gestel dat as konsumasie een maal plaasgevind het, die huwelik 'n onverbreekbare band was. Die doel van huweliksluiting, volgens die Kerk, was om 'n lewenskonsortium daar te stel, om kinders te verwek en om vleeslike lus te bevredig.

12 In die Kanonieke reg is tussen sponsalia de praesenti en sponsalia de futuro onderskei. Eersgenoemde het 'n huwelik daargestel en was die verklaring van die partye waardeur hulle met mekaar in die huwelik getree het. Laasgenoemde kan eerder as die verlowingshandeling gesien word, aangesien dit die onderneming was om in die toekoms met mekaar in die huwelik te tree.

13 Geheime sponsalia de praesenti het inderdaad 'n geldige huwelik tot gevolg gehad. Daarbenewens het 'n geldige huwelik gevolg uit sponsalia de futuro wat deur saamslaap gevolg is. Die moontlikheid van klandestine huwelike wat hierdeur geskep is, het die problematiek rondom regsekerheid in gedrang gebring. Kinders wat nie kon aantoon dat hulle ouers wettig getroud was nie, het buite-egtelike status gehad en huwelike binne bepaalde grade van verbode verwantskap het voorgekom. So ook het huwelike deur minderjariges sonder die toestemming van hulle ouers voorgekom. Om laasgenoemde probleem die hoof te bied het Karel V in artikel 17 van die die Ewige Edik van 1540 voorgeskryf dat 'n persoon wat met 'n minderjarige in die huwelik tree sonder dat dié se ouers tot die huwelik toestemming gegee het, geen finansiële voordeel uit die huwelik kon kry nie. 
de Kerk publicatie van het voorgenomen huwelijk voor, die moest geschieden door drie afkondigingen in de Kerk (algemeen sedert het Vierde Lateraans concilie van 1215), wel verlangde zij inzegening van het huwelijk door een priester, maar op overtreding van deze voorschriften waren alleen kerkelijke straffen en geen nietigheid gesteld (De Blécourt \& Fischer, 1950:67; kursivering JAR).

Die Konsilie van Trente van 1545-1563 was 'n daadwerklike poging van die Kerk om klandestine huwelike te verhoed. Op 11 November 1563 word met die decretum Tametsi (De Reformatione Matrimonii) op straf van nietigheid vereis dat aanstaande eggenote hulle wilsverklaring om 'n huwelik te sluit (sponsalia de praesenti) in teenwoordigheid van 'n priester en twee of drie getuies moes aflê en dat die gebooie afgekondig moes word. Die priester het hierna die huwelik ingeseën. 14

Wat huweliksluiting in hierdie periode betref, kan derhalwe tot die gevolgtrekking geraak word dat dié bedeling aanvanklik die moontlikheid van klandestine huwelike gelaat het, maar dat sodanige geheime huwelike later verbied is ter wille van regsekerheid op sanksie van nietigheid. Ook kon nie duidelik onderskei word tussen die ooreenkoms om in die toekoms met mekaar in die huwelik te tree (sponsalia de futuro) en die huweliksluiting self (sponsalia de praesenti) nie.

\subsection{Die Romeins-Hollandse reg - die invloed van die Protestantisme}

$\mathrm{Na}$ die Reformasie het die wetgewende en regsprekende gesag van die Rooms-Katolieke Kerk in 'n beduidende mate verval en hierdie tipe gesagsfunksies is deur Protestantse kerklike ampsdraers en sekulêre ampsdraers uitgevoer (De Blécourt \& Fischer, 1950:68). Ofskoon die huwelik nie in hierdie periode as 'n sakrament gesien is nie, is daar steeds aan die gedagte vasgehou dat dit ' $n$ instelling van goddelike oorsprong is. Die huwelik word in hierdie periode burgerregtelik gereguleer. Die Politieke Ordonnansie van die State van Holland van 1580, wat op die decretum Tametsi geskoei is, bepaal byvoorbeeld dat die gebooie behoorlik drie maal afgekondig

14 Vergelyk De Blécourt en Fischer (1950:68) en Hahlo (1969:8). Dit is belangrik om daarop te let dat die bepalings van die Konsilie van Trente nie deel van die reg van noordelike Nederland geword het nie. Die Politieke Ordonnansie van 1580 het egter wel die bepalings van die decretum Tametsi aanvaar. Vergelyk ook Van der Vyver en Joubert (1991:460). 
moes word en dat die huwelik deur 'n predikant van die kerk of deur 'n landdros in die teenwoordigheid van ten minste twee getuies voltrek moes word.15 Indien hierdie vereistes nie nagekom is nie, was die huwelik nietig. ${ }^{16}$

Wilsooreenstemming was in hierdie periode nie voldoende om 'n regsgeldige huwelik tot stand te bring nie - die huwelik is voltrek sodra die bevestiging daarvan in die kerk deur 'n predikant of voor ' $n$ landdros geskied het. Saamslaap was geen vereiste nie (Lee, 1926:29). Dit is egter belangrik om te let op die onderliggende oorwegings wat gelei het tot die vereistes vir die formele bevestiging van huwelike. Grotius, soos vertaal deur Lee, sit die posisie soos volg uiteen:

In old times marriage used to be contracted in these Provinces without much ado; in some places all that was required was concubitus with the knowledge of the relatives on both sides; but as this caused many discontents and scandals, because some persons contracted marriage in breach of previous espousals, or with persons nearly related by blood or affinity, sometimes also without previous consent of those who were entitled to be acquainted therewith; therefore, for the prevention of all this, the States further ordained by the same enactment that all persons who wished to give themselves in marriage should be required to appear before the magistrates or the ministers of the Church of their domicile, and there request proclamation of banns on three Sundays or market days, to be made in the church, or from the council-house or other place where justice is done, to the end that every person who had any let or hindrance to allege why the marriage should not proceed might do so in good time ... (Lee, 1926:27; kursivering - JAR).

Regsproses met betrekking tot huweliksaangeleenthede is voorts ook in burgerlike tribunale afgehandel.

15 Die Politieke Ordonnansie het uitvoerige voorskrifte aangaande die vereistes vir huweliksluiting bevat. Hierdie voorskrifte is tans nog van deurslaggewende belang vir die Suid-Afrikaanse reg, byvoorbeeld die voorskrifte rondom verbode grade van verwantskap.

16 De Blécourt en Fischer (1950:68) dui aan dat in die provinsie Holland huwelike deur predikante van die Gereformeerde Kerk in die kerk voltrek is. "Dissenters" (lidmate van Protestante sektes wat van die gereformeerde (Reformatoriese) leer afgewyk het), Rooms-Katolieke en Jode se huwelike is deur die "wereldlijke overheid, het gerecht, in het openbaar" voltrek. 


\subsection{Die Suid-Afrikaanse reg}

\subsubsection{Kort historiese oorsig}

Met die koms van Jan van Riebeeck na die Kaap die Goeie Hoop is die Romeins-Hollandse reg soos dit na die Kerkhervorming gegeld het, hier te lande toegepas.17 Tot 1665 toe die eerste kerkleraar aangestel is, is huwelike deur die sekretaris van die Politieke Raad bevestig, nadat die gebooie drie maal afgekondig is. Ná hierdie datum is huwelike deur die leraar voltrek. Tot 1676 moes by die Politieke Raad aansoek gedoen word om die gebooie af te kondig en eers nadat die aansoek ondersoek is en geen besware teen die voorgenome huwelik ontvang is nie, is die nodige toestemming deur die Raad verleen. Lede van die Raad moes by die huwelikseremonie teenwoordig wees. Op 31 Desember 1676 is die Collegie van Commissarissen van Huwelijks Zaken in die lewe geroep. Die Collegie het bestaan uit twee amptenare van die Kompanjie en twee burgers en persone wat in die huwelik wou tree moes persoonlik voor die Collegie verskyn om toestemming te versoek om in die huwelik te tree. Die Collegie se opdrag was om vas te stel of daar regtens enige beletsels tot die voorgenome huwelik bestaan het. As geen sodanige beletsels bestaan het nie, is toestemming verleen dat die gebooie afgekondig en die huwelik gesluit kon word. Van der Vyver en Joubert (1991:460) toon aan dat die uitgestrektheid van die regsgebied van die Kaap vereis het dat ander plaaslike liggame vir dié doel ingestel moes word. Die hof van die landdros en heemrade het dus die bepaalde funksies oorgeneem.

In 1804 het Kommissaris De Mist 'n volledig sekulêre huwelik ingestel. 'n Huwelik sou voortaan slegs deur 'n landdros en heemrade bevestig kon word. By die aanvang van die Tweede Britse besetting van die Kaap het sir David Baird egter in 1806 sodanige huweliksluiting verbied. 'n Huwelik moes deur 'n leraar bevestig word. In 1838 is die Marriage Order in Council uitgevaardig. Die

17 Daar bestaan geen twyfel nie dat die voorskrifte van die Politieke Ordonnansie en die Ewige Edik die grondslag van die Suid-Afrikaanse huweliksreg gevorm het. Daar is egter onduidelikheid oor die vraag of dit ook die posisie was ten aansien van die Echtreglement over de Steden, ende ten platen Lande, inde Heerlijkckheden, ende Dorpen, staende onder de Generaliteyt van die StateGeneraal van 1656. In 'n aantal sake, waaronder Cloete $v$ Resident Magistrate, Elliot 1914 CPD 1075; Estate Heinamann v Heinamann 1919 AD 99; Pretorius v Pretorius 1942 OPD 173, word te kenne gegee dat die Echtreglement wel deel van die Suid-Afrikaanse reg geword het. Hahlo (1969:15) dui egter aan dat dit aan die foutiewe aanname toegeskryf kan word dat die Echtreglement in Holland gegeld het. 
Order het die vereistes vir huweliksluiting, waaronder die afkondiging van gebooie en die aanstelling van huweliksbevestigers, uiteengesit. Die Marriage Act 16 van 1860 van die Kaapprovinsie het opnuut voorsiening gemaak vir huweliksbevestiging deur 'n resident-landdros, sodat burgerlike huwelike voortaan die voorgeskrewe huweliksvorm sou wees. Die reëlings wat in die Kaapprovinsie gegeld het, is mettertyd deur die ander provinsies oorgeneem. Hierdie reëlings het ná Uniewording steeds afsonderlik voortbestaan. Wetgewing het egter wel tot stand gekom wat eenvormige voorskrifte vir die Unie bevat het. Eers in 1961 het die Huwelikswet (25 van 1961) egter eenduidige voorskrifte met betrekking tot huweliksluiting uiteengesit. In wese bepaal hierdie wet steeds die formaliteite vir regsgeldige huweliksluiting.

\subsubsection{Die Huwelikswet 25 van 1961}

Dit is toelaatbaar om die gestelde voorskrifte van die Huwelikswet te vervat in gebruiklike seremonies van 'n godsdienstige groepering (Art. 30(2) van die Huwelikswet 25 van 1961). Die Minister van Binnelandse Sake mag ook toestemming verleen dat 'n huwelik bevestig word ooreenkomstig die huweliksformulier wat binne 'n bepaalde godsdienstige groepering gebruiklik is. Die huwelik is voltrek sodra die huweliksbevestiger verklaar dat die partye getroud is. ${ }^{18}$ Indien 'n voorskrif van die Huwelikswet wesenlik is, kan die nienakoming daarvan tot die nietigheid van die huwelik lei. Artikel 30 van die Huwelikswet bepaal egter uitdruklik dat indien bepalings aangaande die huwelikseremonie (formulier, gee van die regterhand, verklaring dat die partye getroud is) as gevolg van 'n versuim of 'n oorsig te goeder trou deur die partye of die huweliksbevestiger, of as gevolg van die liggaamlike ongeskiktheid van een of albei die partye nie stiptelik nagekom is nie, die huwelik steeds geldig sal

18 Blote ooreenkoms tussen die partye stel nie 'n regsgeldige huwelik daar nie. Andersyds word die registrasie van die huwelik of saamslaap nie vereis om 'n geldige huwelik daar te stel nie. Registrasie geskied bloot ter wille van die openbare belang, aangesien die besonderhede van die huwelik aangeteken word. Dit vergemaklik dit om die bestaan van die huwelik te bewys. Hahlo (1969:6) toon aan dat dit in die Engelse reg moontlik is dat blote wilsooreenstemming ' $n$ regsgeldige huwelik kan daarstel in gevalle van oorlog, burgerlike opstand, natuurrampe of aanhouding in 'n konsentrasiekamp. Daar word aan die hand gedoen dat die Suid-Afrikaanse howe dieselfde benadering sal volg. 
wees as aan alle ander vereistes voldoen is en dit nie op grond van ander oorwegings betwis kan word nie. ${ }^{19}$

'n Verdere aspek wat in hierdie verband voor oë gehou moet word, is die stelreël dat as daar getuienis van 'n huwelikseremonie is wat deur saamslaap gevolg is, daar vermoed word dat aan die vereistes vir 'n geldige huwelik voldoen is - semper praesumitur pro matrimonio. Ofskoon dit normaalweg nie afdoende bewys van die bestaan van ' $n$ regsgeldige huwelik vir die doeleindes van egskeiding sal wees nie, sal bewys van saamslaap 'n weerlegbare vermoede skep dat 'n regsgeldige huwelik bestaan (Hahlo, 1969:8).

Daar moet beklemtoon word dat, nieteenstaande die voorskrifte van die Huwelikswet, daar regtens geen verbod bestaan wat verhoudings van seksuele aard tussen persone verbied nie. Partye kan byvoorbeeld besluit om saam te woon en hulle verhouding deur middel van ' $n$ kontrak te laat beheers. ${ }^{20}$ Dit is duidelik dat partye ' $n$

19 Vergelyk Van der Vyver en Joubert (1991:514) en Hahlo (1969:81). In Ex parte Dow 19873 SA 829 (D \& CLD) was die vraag voor die hof wat die status van 'n huwelik was wat nie in 'n gebou voltrek was nie. Artikel 29(2) van die Huwelikswet skryf voor dat 'n huwelik in bepaalde geboue voltrek moet word. Die vraag is derhalwe of die imperatiewe aard van die voorskrif beteken dat 'n huwelik wat nie so voltrek is nie, nietig sal wees. Die hof kom, ná 'n regshistoriese oorsig, tot die volgende gevolgtrekking:

\begin{abstract}
In my view the object of these provisions was essentially to ensure that marriages took place in public, that the public were to be informed of intended marriage so that any objections could be raised, and that a register to which the public had access be kept. The constant reference to open doors is an indication that the public were to be permitted access to every marriage ceremony, the mischief being clandestine marriages. ... I have not been able to ascertain the basis for, or object of, the requirement that a marriage must be solemnized in a private dwelling as opposed to at, or in the precincts of, a private dwelling.
\end{abstract}

Die vereistes rondom die afkondiging van die gebooie wat voorheen in die Huwelikswet gestel, is in 1970 van die wetboek verwyder.

20 Daar moet daarop gelet word dat selfs poligame verbintenisse nie spesifiek in die Suid-Afrikaanse reg verbied word nie. Sodanige verbintenisse, uitgesluit dié ooreenkomstig die voorskrifte van die Wet op Erkenning van Gebruiklike Huwelike 120 van 1998, word egter met die sanksie van nietigheid getref. Voorheen was sodanige huwelike nietig, aangesien daar nie aan die vereistes van die Huwelikswet voldoen is nie en omdat dit poliginie toelaat (poliginie = huwelik van 'n man met meer as een vrou tegelykertyd - volgens stamgebruik). $\mathrm{Na}$ die inwerkingtrede van die Wet op Erkenning van Gebruiklike Huwelike 120 van 1998 word sodanige huwelike nou as regsgeldig erken. Hierdie huwelike het bepaalde onderskeidende kenmerke wat die volgende insluit: die groepsaard van die huwelike, die lewering van lobolo, die moontlikheid dat die huwelik poligeen kan wees en die belang daarvan dat kinders uit 'n huwelik gebore word. 
keuse gelaat word of hulle hulle van bepaalde regsvoorskrifte wil laat bedien. Indien partye dus om bepaalde redes (byvoorbeeld godsdienstig van aard) nie die regsvoorskrifte in verband met huweliksluiting kan of wil nakom nie en die weiering of versuim van so ' $n$ aard is dat dit tot die nietigheid van die huwelik aanleiding gee, kan hulle steeds saamwoon, 'n gesin vestig en 'n eiesoortige goederebedeling daarstel. 21

'n Belangrike onderskeid wat van belang is in hierdie argument, handel daaroor dat daar onderskei word tussen die reg wat vir regsubjekte as lede van die staatlike gemeenskap geld en dié wat vir regsubjekte as lede van ander gemeenskappe as die staat geld. In die Suid-Afrikaanse konteks is hierdie onderskeid van besondere belang, aangesien huwelike wel volgens die voorskrifte van 'n bepaalde godsdienstige groepering gesluit kan word, welke voorskrifte in stryd met regsvoorskrifte is wat geld om ' $n$ regsgeldige handeling uit te voer. Indien persone dus volgens die voorskrifte van 'n bepaalde godsdienstige groepering in die huwelik tree sonder om aan die statutêr voorgeskrewe vereistes te voldoen, sal die huwelik regtens nietig wees, maar vir die doeleindes van die dogma van die bepaalde groepering, sal dit wel geldig wees. Die gevolge wat deur die reg van die groepering voorgeskryf word, sal op die verhouding betrekking hê.22

\section{Slot}

Die grondslae van die huwelik as instelling lê regshistories nie binne die staatlike domein nie, maar eerder binne die nie-staatlike. In die Romeinse, Germaanse en vroeë Kanonieke reg is die huwelik uitsluitlik 'n privaat aangeleentheid met die aard van uniek individuele en familiebetrokkenheid. Informele wilsooreenstemming sonder die nakoming van vereistes wat van regsweë gestel is, was voldoende om 'n huweliksverhouding te skep. Wanneer 'n huwelik egter tot stand gekom het, het bepaalde regsgevolge wel uit die huwelik voortgevloei. In die latere Kanonieke reg en ook in die Romeins-Hollandse en Suid-Afrikaanse reg word gevind dat voldoening aan statutêr voorgeskrewe vereistes 'n regsgeldige

21 Vir 'n volledige uiteensetting van die geldingswyse as indelingskriterium van die objektiewe reg, kan onder andere gekyk word na Van der Vyver en Joubert, (1991:339).

22 Vergelyk Van der Vyver en Joubert (1991:339 e.v.) vir 'n uiteensetting van die staatlike en nie-staatlike positiewe reg as indelingskriterium van die objektiewe reg. 
huwelik daarstel. Dit blyk egter dat die nakoming van dié vereistes eerder gesien moet word as 'n aanduiding van die keuse van die partye, nie alleen om aan relevante regsvoorskrifte te voldoen nie, maar ook om binne die raamwerk van die staatlike reg bepaalde regsgevolge aan hulle verhouding (huwelik) te knoop. Die keuse word van regsweë aan partye gelaat of hulle binne 'n formele huwelik, wat 'n bepaalde status vir die partye skep, of bloot informeel ooreenkomstig die bepalings van 'n (ook stilswyende) kontrak, saam wil woon.

Uit die voorafgaande bespreking blyk die volgende duidelik:

- die nakoming van huweliksformaliteite word ter wille van regsekerheid en die bekamping van klandestine huwelike vereis;

- die geykte reg is dat persone wat wil saamwoon, nie van regsweë verplig word om 'n regsgeldige huwelik te sluit nie; en

- nie-staatlike instansies (waaronder die kerk) kan inderdaad vir eie en interne verbandsdoeleindes voorskrifte maak vir die geldigheid van huwelike.

Op grond van die voorafgaande kan tot die gevolgtrekking geraak word dat dit kerkverbande vry staan om volgens eie dogma en leer voorskrifte vir die geldigheid van huwelike te maak. In hierdie verband is die waarskuwing van Dooyeweerd steeds relevant:

The fact that Christians have come to look upon the marriage bond as essentially a juridical institution must be denounced as a fundametal deformation of the Biblical view of this natural community. ${ }^{23}$ (kursivering - JAR; bespreking onder paragraaf 1 ).

23 Vergelyk Dooyeweerd ((n 13) 312). Ofskoon dit buite die fokus van hierdie artikel val, is dit wel van waarde om kortliks toeligting te bied aangaande die "natural community", soos Dooyeweerd dit stel. Binne die Reformatoriese tradisie word die huwelik gedefinieer as 'n sosiale entiteit wat deur 'n tipiese struktuur gekenmerk word. Die eie-aard van hierdie struktuur lê opgesluit in die samehang van twee besondere funksies van die sosiale entiteit, naamlik die funderings- en die bestemmingsfunksies onderskeidelik. Die funderingsfunksie is daarop gerig om die besondere eenheid van die entiteit te waarborg, terwyl die bestemmingsfunksie rigtinggewend die voleinding van die entiteit aandui. As sodanig is die huwelik in die biologiese gefundeer en gebaseer op die seksuele verskille tussen man en vrou. Die intieme eenheid van die huweliksband word gewaarborg deur die seksuele basis wat in geslagsomgang tussen die partye tot uitdrukking kom. Daarteenoor vind die huweliksband sy bestemming in die etiese aspek wat in die onderlinge liefdesbetoon tussen die partye tot uitdrukking kom. 


\section{Geraadpleegde bronne}

DE BLÉCOURT, A.S. \& FICHER, H.F.W.D. 1950. Kort begrip van het OudVaderlands Burgerlijk recht. Groningen: Wolters-Noordhoff.

DOOYEWEERD, H.J. 1957. A new critique of theoretical thought. Vol. 3.

DOUMA, J. 1990. Etiek en recht. Kampen: Van den Bergh.

HAHLO, H.R. 1969. The South African law of husband and wife. Cape Town: Juta.

HEYNS, J.A. 1981. Etiek van die liefde. Pretoria: Daan Retief.

LEE, R.W. 1926. Grotius jurisprudence of Holland. Vol. I. Oxford: Clarendon.

MOYLE, J.B. 1912. Imperatoris Iustiniani Institutiones. Oxford: Clarendon.

MUIRHEAD, J. 1899. Historical introduction to the private law of Rome. London: Black.

STONEY, S. 1896. Voet Commentarius ad Pandectas. Book 23, Title 2 - On marriage laws. Cape Town: Miller.

VAN DER VYVER, J.D. \& JOUBERT, D.J. 1991. Persone- en familiereg. Kaapstad: Juta.

VAN WARMELO, P. 1971. 'n Inleiding tot die studie van die Romeinse reg. Kaapstad: Balkema.

\section{Sake:}

Cloete v Resident Magistrate, Elliot 1914 CPD 1075

Du Toit v Minister of Welfare and Population Development 2001 (12) BCLR $1225(\mathrm{~T})$

Estate Heinamann v Heinamann 1919 AD 99

Ex parte Dow 19873 SA 829 (D \& CLD)

Fourie \& Bonthuys v Minister of Home Affairs Saak no 232/2003

Grobbelaar v Havenga 19643 SA 522 (W); T v T 19683 SA 554 (R))

Joshua v Joshua 19611 SA 455 (GW)

Langemaat v Minister of Safety and Security 19982 All SA 259 (T) Satchwell v President of the Republic of South Africa 20026 SA 1 (CC)

Pretorius v Pretorius 1942 OPD 173

\section{Wette}

Huwelikswet 25 van 1961

Marriage Act 16 van 1860

Wet op Erkenning van Gebruiklike Huwelike 120 van 1998

\section{Kernbegrippe:}

huwelik: regsgeldigheid

huweliksformaliteite

huweliksinstelling: regshistoriese agtergrond

\section{Key concepts:}

marriage: formalities for

marriage: validity of

marriage institution: legal-historical background 
